\begin{tabular}{|c|c|c|}
\hline BIODIK & $\begin{array}{c}\text { BIODIK: Jurnal IImiah Pendidikan Biologi } \\
\text { ISSN 2580-0922 (online), ISSN 2460-2612 (print) } \\
\text { Volume 07, Nomor 03, Tahun 2021, Hal. 195-204 } \\
\quad \text { Available online at: } \\
\text { https://online-journal.unja.ac.id/biodik }\end{array}$ & BIODIK Q \\
\hline
\end{tabular}

Research Article

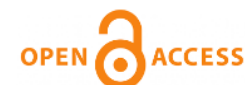

\title{
Inovasi Pembelajaran Mata Kuliah Pembelajaran Mikro Berbasis Model PjBL (Project Based Learning) Untuk Meningkatkan Kreativitas Mahasiswa
}

\author{
(Learning Innovation of Micro Learning Courses Based on The PjBL (Project Based Learning) \\ Model to Increase Student Creativity)
}

Ali Sadikin*, Upik Yelianti

Program Pendidikan Biologi, Universitas Jambi

JI. Raya Jambi-Ma.Bulian KM 15 Mendalo Indah-Muaro Jambi, Jambi 36361

${ }^{*}$ Corresponding author: alisadikin@unja.ac.id

\begin{tabular}{|c|c|}
\hline Informasi Artikel & ABSTRACT \\
\hline $\begin{array}{l}\text { Submit: } 06-06-2021 \\
\text { Diterima: } 22-08-2021 \\
\text { Dipublikasikan: } 30-09-2021\end{array}$ & $\begin{array}{l}\text { Good learning is innovative learning following the times. To support the vision } \\
\text { and mission of the Jambi Smart University, changes will be made to the micro } \\
\text { learning courses in the biology education study program. The change is learning } \\
\text { innovation using the PjBL (Project Based Learning) learning model. With this } \\
\text { PjBL model, learning tools, teaching materials, and evaluation instruments will } \\
\text { be developed to increase student creativity in the Biology Education Study } \\
\text { Program, FKIP Jambi University. The research method uses classroom action } \\
\text { research (CAR) which is planned for } 2 \text { cycles. The stages include: planning, } \\
\text { implementation and observation, and reflection. At the planning stage, a small } \\
\text { discussion was held between the teaching team and agreed on the } \\
\text { implementation of PJBL. At the implementation stage, students make a project } \\
\text { in the form of a learning video containing teaching skills. At the observation stage: } \\
\text { students are asked to present their project in front of the class virtually, then } \\
\text { lecturers and colleagues observe and provide feedback. Finally, the reflection } \\
\text { stage, input and comments from lecturers and colleagues are recorded and } \\
\text { project improvements are made. In the first cycle, the results of the observation } \\
\text { were } 55 \% \text { in the pretty good category. Then improvements were made from input } \\
\text { and comments from lecturers and colleagues, so that in the second cycle there } \\
\text { was an increase in student creativity at a score of } 80 \% \text { in the good category. } \\
\text { Key words: PjBL learning model, Micro learning, biology }\end{array}$ \\
\hline Penerbit & ABSTRAK \\
\hline $\begin{array}{l}\text { Program Studi Pendidikan Biologi } \\
\text { FKIP Universitas Jambi, } \\
\text { Jambi- Indonesia }\end{array}$ & $\begin{array}{l}\text { Pembelajaran yang baik adalah pembelajaran yang inovatif mengikuti } \\
\text { perkembangan zaman. Untuk mendukung visi dan misi Universitas Jambi smart } \\
\text { maka mata kuliah pembelajaran mikro di prodi pendidikan biologi akan diadakan } \\
\text { perubahan. Perubahan itu adalah inovasi pembelajaran menggunakan model } \\
\text { pembelajaran PjBL (Project Based Learning). Dengan model PjBL ini akan } \\
\text { dikembangkan perangkat pembelajaran, bahan ajar, dan instrument evaluasi } \\
\text { untuk meningkatkan kreativitas mahasiswa di Prodi Pendidikan Biologi FKIP } \\
\text { Universitas Jambi. Metode penelitian mengunakan penelitian tindakan kelas } \\
\text { (PTK) yang direncanakan } 2 \text { siklus. Adapun tahapnnya meliputi: perencanaan, } \\
\text { pelaksanaan dan observasi, dan refleksi. Pada tahap perencanaan dilakukan } \\
\text { diskusi kecil antar tim pengajar dan disepakati penerapan PJBL. Pada tahap } \\
\text { pelaksanaan mahasiswa membuat proyek berupa video pembelajaran yang } \\
\text { berisi keterampilan mengajar. Pada tahap pengamatan: mahasiswa diminta }\end{array}$ \\
\hline
\end{tabular}


untuk mempresentasikan proyeknya tersebut didepan kelas secara virtual, kemudian dosen dan teman sejawat mengamati dan memberikan umpan balik. Terakhir tahap refleksi masukan dan komentar dari dosen dan teman sejawat dicatat dan dilakukan perbaikan proyek. Pada siklus 1 diperoleh hasil pengamatan $55 \%$ kategori cukup baik. Lalu diadakan perbaikan dari masukan dan komentar dari dosen dan teman sejawat maka pada siklus II mengalami kenaikan kreativitas mahasiswa pada skor $80 \%$ dalam kategori baik.

Kata kunci: Model Pembelajaran PjBL, Pembelajaran Mikro, Biologi

\section{(1) (2)}

BY Ne SA

This BIODIK : Jurnal IImiah Pendidikan Biologi is licensed under a CC BY-NC-SA (Creative Commons Attribution-ShareAlike 4.0 International License)

\section{PENDAHULUAN}

Inovasi pembelajaran di perguruan tinggi perlu dilakukan mengingat perkembangan zaman dan kebutuhan mahasiswa untuk lebih kreatif adalah tuntutan pendidikan abad 21. Dalam pembelajaran abad 21 dituntut untuk dapat membelajarakan secara kolaboratif (Collaboration), Kreatif (Creativity), Komunikatif (Communication) dan berpikir kritis (Critical Thinking) atau yang lebih dikenal dengan $4 \mathrm{C}$ (Sudarisman, 2015). Salah satu inovasi pembelajaran yang dapat dilakukan adalah dengan menerapkan model pembelajaran berbasis proyek (Project Based Learning-PjBL). Dengan PjBL ini diharapkan Universitas Jambi dapat meningkatkan peringkatnya baik pada tataran nasional maupun internasional. (LPPM, 2021). Dengan model pembelajaran PjBL ini diharapkan dapat meningkatkan mutu pembelajaran di Universitas Jambi. Sebab dengan terobosan baru dari para dosen akan dapat meningkatkan mutu pembelajaran (Jouwe et al., 2018).

Model Pembelajaran PjBL adalah Serangakaian kegiatan pembelajaran dari awal sampai akhir yang didalamnya guru memberikan proyek-proyek kepada siswa untuk diselesaikan guna mendapatkan ilmu pengetahuan untuk meningkatkan kreativitas (Sari \& Angreni, 2018). Lebih lanjut (Surya et al., 2018) model PjBL adalah kegiatan belajar mengajar yang melibatkan peserta didik secara aktif dalam memecahkan masalah dan memberikan peluang kepada mereka untuk lebih mengekspresikan kreatifitasnya sehingga dapat meningkatkan kreativitas dan hasil belajar.

Kreativitas adalah suatu proses mental dalam menghasilkan sesuatu yang tidak dapat dibuat oleh orang lain, berbeda, hal yang baru dan memiliki nilai serta berdaya guna (Surya et al., 2018). Kreativitas adalah kemampuan dalam memproses sesuatu menggunakan daya fikir orisinal yang berbeda dengan orang lain, berani berbeda, berani mengambil risiko apabila salah dan ada kepuasan tersendiri bagi pelakunya. Dapat ditarik kesimpulan dari pendapat para ahli bahwa kreativitas adalah kemampuan untuk mengeksperikan diri, yang berani berbeda dengan orang lain, baik individu maupun berkelompok dengan menggunakan daya fikir original guna mendapatkan gagasan, ide dang prosedur yang memiliki daya guna.

Faktor-faktor yang dapat mempengaruhi kreativitas peserta didik adalah memberi kesempatan untuk berpikir, memberikan dorongan, dan sarana (Jouwe et al., 2018; Surya et al., 2018). Pada kesempatan ini faktor yang peneliti gunakan untuk meningkatkan kreativitas peserta didik adalah dorongan, sarana dan waktu. Lebih dari pada itu, ternyata juga ada faktor penghalang dalam usaha meningkatkan kreativitas peserta didik diantaranya pembatasan keingintahuan peserta didik, usia peserta didik yang terlalu dini, tidak beraninya peserta didik mengeluarkan kemampuannya, dan terlalu banyak larangan dan aturan (Fitrisia \& Jalinus, 2019). Kreativitas memiliki ciri tersendiri yang terdiri dari 4 macam 
yaitu keluwesan (Fleksibility), kelancaran (Fluency), keaslian (originality) dan peguraian (elaboration) (Anugraheni, 2018).

Salah satu mata kuliah yang perlu untuk ditingkatkan mutu pembelajarannya di Prodi Pendidikan Biologi FKIP Universitas Jambi adalah mata kuliah pembelajaran mikro atau micro-teaching. Pembelajaran mikro merupakan mata kuliah untuk meningkatkan keterampilan mengajar calon guru. Proses pembelajaran yang diselenggarakan dengan menyederhanakan waktu, materi, jumlah siswa, jenis ketrampilan dasar mengajar, penggunaan metode, media dan lain lain. Dengan mata kuliah ini diharapkan mahasiswa memiliki keterampilan membuka dan menutup pelajaran, mengelola kelas baik tatap muka maupun virtual, mengadakan variasi dalam mengajar, dan keterampilan menjelaskan. Pembelajaran mikro (Micro-teaching) adalah suatu proses pembelajaran dan praktik yang mengintegrasikan teori yang telah dipelajari dengan kegiatan praktik mengajar di kelas dengan waktu yang sudah dikondisikan, siswa yang terbatas, dengan paket materi tertentu dan dilaksanakan di laboratorium khusus mengajar (Allen, 1979; Amobi, 2005; Benedetti \& Reed, 1998).

Pembelajaran mikro adalah melatih calon guru untuk belajar mengajar dengan menerapkan tiga kali siklus yaitu 2 kali siklus di kelas perkuliahan dan satu kali siklus di kelas sebenarnya yaitu di sekolah (Stahl et al., 2018). Lebih lanjut, pembelajaran mikro adalah pengintegrasian teori dan praktik bagi calon guru untuk meningkatkan kemahirannya dalam mengajar, melatih pengalaman, dan meningkatkan kepercayaan diri (Royea \& Nicol, 2018). Perkembangan terakhir pembelajaran mikro di Jepanag mengalami improvisasi dengan menggunakan boneka sebagai media latihan micro-teaching. Boneka tersebut berperan menggantikan guru dan siswa yang digerakkan, hal ini dilakukan untuk menarik motivasi mahasiswa dalam mempraktikkan latihan mengajar. (Wakimoto et al., 2019).

Maka dari itu mata kuliah pembelajaran mikro ini perlu untuk diterapkan juga inovasi dengan menggunakan model PjBL. Dengan PjBL dosen dapat merancang pembelajaran menggunakan contohcontoh kasus dalam pembelajaran yang akan diberikan kepada mahasiswa untuk dianalisis. Dengan proyek yang diberikan berupa kasus atau permasalahan misalnya contoh-contoh kesalahan guru dalam mengajar, kasus guru dengan siswa, dan kesulitan guru pemula. Kasus-kasus tersebut mahasiswa dianalisis mahasiswa untuk dicarikan solusi kreatif atau pemecahannya kemudian dipraktikan dalam pembelajaran biologi. Maka dari itulah dirasa perlu untuk meneliti Inovasi Pembelajaran Maka Kuliah Pembelajaran Mikro Berbasis Model PjBL (Project Based Learning) Untuk Meningkatkan Kreativitas Mahasiswa.

\section{METODE PENELITIAN}

Rancangan penelitian menggunakan penelitian tindakan kelas (PTK). Penelitian tindakan kelas adalah penelitian yang dilakukan di dalam kelas menggunakan suatu tindakan untuk meningkatkan kualitas proses belajar mengajar agar diperoleh hasil yang lebih baik dari sebelumnya. Penelitian tindakan kelas membutuhkan waktu yang tidak sebentar karena harus bisa mengimplementasikan tindakan beserta variabel yang sudah dirancang untuk mencapai hasil yang dikehendaki. Dalam penelitian ini variable $X$ yang akan digunakan adalah model pembelajaran $P j B L$ dan variable $Y$ adalah kreativitas mahasiswa. Model PTK yang digunakan adalah model PTK Kurt Lewin. Komponen pokok yang dilakukan pada Model PTK Kurt Lewin meliputi perencanaan, tindakan, pengamatan, dan refleksi. 


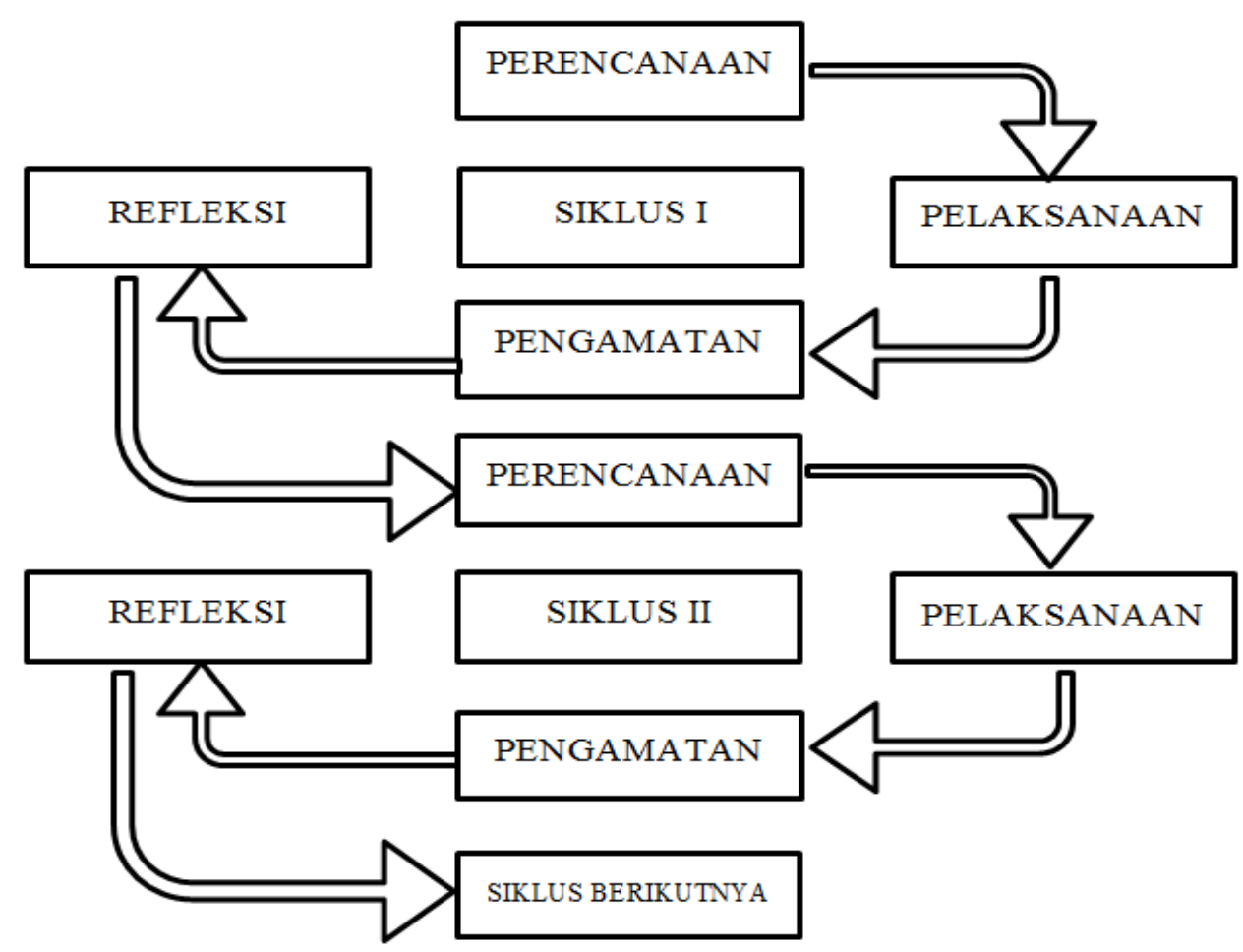

Gambar 1. Siklus Penelitian Tindak Kelas

\section{Prosedur Penelitian}

Model PTK yang digunakan adalah model PTK Kurt Lewin. Komponen pokok yang dilakukan pada Model PTK Kurt Lewin meliputi perencanaan, tindakan, pengamatan, dan refleksi. Dalam PTK yang akan digunakan terdiri dari dua siklus. Setiap siklusnya terdiri dari empat tahap berikut.

\section{Tahap perencanaan}

Pada tahap ini, peneliti akan mempersiapkan dengan matang konsep penelitian yang akan dijalankan, yaitu model pembelajaran PjBL untuk meningkatkan kreativitas mahasiswa.

\section{Tahap pelaksanaan}

Tahap pelaksanaan adalah tahap penting penentu keberhasilan penelitian. Pada tahap ini peneliti akan mengeksekusi rencana yang telah dibuat. Pada tahap ini, peneliti akan mengajar dengan baik dan sesuai rencana yang telah dipersiapkan.

\section{Tahap pengamatan}

Pada tahap pengamatan, ada dua hal yang harus di amati, yaitu kegiatan belajar mahasiswa dan kegiatan mengajar dosen. Kegiatan belajar mahasiswa dapat di pantau selama proses pembelajaran berlangsung. Sementara itu, kegiatan mengajar dosen akan dipantau oleh orang lain (kolaborator) dalam hal ini tim penelitian. 


\section{Tahap refleksi}

Tahap refleksi akan dilakukan diskusi antara dosen pengajar dengan kolaborator atau tim penelitian. Diskusi bertujuan untuk membagikan hasil pengamatan kolaborator terhadap kinerja dosen pengajar di kelas.

\section{Instrumen Pengumpulan Data}

Instrumen pengumpulan data meliputi :

1. Angket digunakan untuk menjaring data tingkat kreativitas mahasiswa sebelum penerapan model PjBL dan sesudah penerapan PjBL.

2. Pedoman wawancara digunakan untuk menjaring data kebutuhan mahasiswa dan dosen terhadap mata kuliaha Pembelajaran Mikro.

\section{HASIL DAN PEMBAHASAN}

\section{SIKLUS I}

\section{A. PERENCANAAN}

Pada tahap perencanaan tim pengajar melakukan diskusi untuk menentukan Rencana Pelaksanaan Perkuliahan (RPS) mata kuliah pembelajaran mikro. Pada kesempatan ini masing-masing dosen memberikan masukan tentang proses perkuliahan yang akan dilaksanakan. Disepakati dalam penyusunan RPS kegiatan yang akan dilakukan dalam perkuliahan adalah penyampaian materi pembelajaran mikro, keterampilan mengajar, keterampilan abad 21 dan HOTS (High other thinking skill) atau yang biasa disebut keterampilan berpikir tingkat tinggi. Setelah itu baru mahasiswa diberikan proyek berupa pembuatan video pembelajaran yang didalamnya berisikan tentang keterampilan mengajar yang digunakan. Mahasiswa diminta untuk membuat skenario untuk membuat proyek yang akan dikerjakan. Termasuk menentukan materi, menentukan media yang akan digunakan dan keterampilan mengajar apa yang akan dilatih.

\section{B. PELAKSANAAN}

Dalam pelaksanaan setiap mahasiswa diminta untuk mempresentasikan proyek yang telah mereka buat. Masing-masing mahasiswa diberikan waktu 15 menit sampai 20 menit untuk mempresentasikan proyek yang telah dibuat. Setelah dilaksanakan presentasi mahasiswa memberikan umpan balik berupa saran, komentar dan masukan terhadap proyek yang telah dibuat. Umpan balik dari teman sejawat ini dicatat untuk dilakukan revisi dalam perbaikan proyek. Dosen selaku supervisor memberikan masukan, komentar dan saran terhadap proyek yang dikerjakan.

Tabel 1. Hasil pelaksanaan proyek

\begin{tabular}{|c|c|c|c|}
\hline No & Mahasiswa & Kesalahan & Saran \\
\hline 1. & ADL & $\begin{array}{l}\text { 1. Gambar pecah dan macet } \\
\text { 2. Keterangan keterampilan mengajar } \\
\text { tidak ada }\end{array}$ & $\begin{array}{ll}\text { 1. Gunakan kamera dengan resolusi } \\
\text { tinggi } \\
\text { 2. Gunakan jaringan yang kuat } \\
\text { 3. Tambahkan keterampilan mengajar }\end{array}$ \\
\hline & NAS & $\begin{array}{l}\text { 1. Keterangan keterampilan mengajar } \\
\text { suda ada tapi tidak sesuai } 8 \\
\text { keterampilan mengajar } \\
\text { 2. Tulisan masih ada yang typo }\end{array}$ & $\begin{array}{l}\text { Berikan keterangan yang sesuai dan hindari } \\
\text { typo }\end{array}$ \\
\hline
\end{tabular}




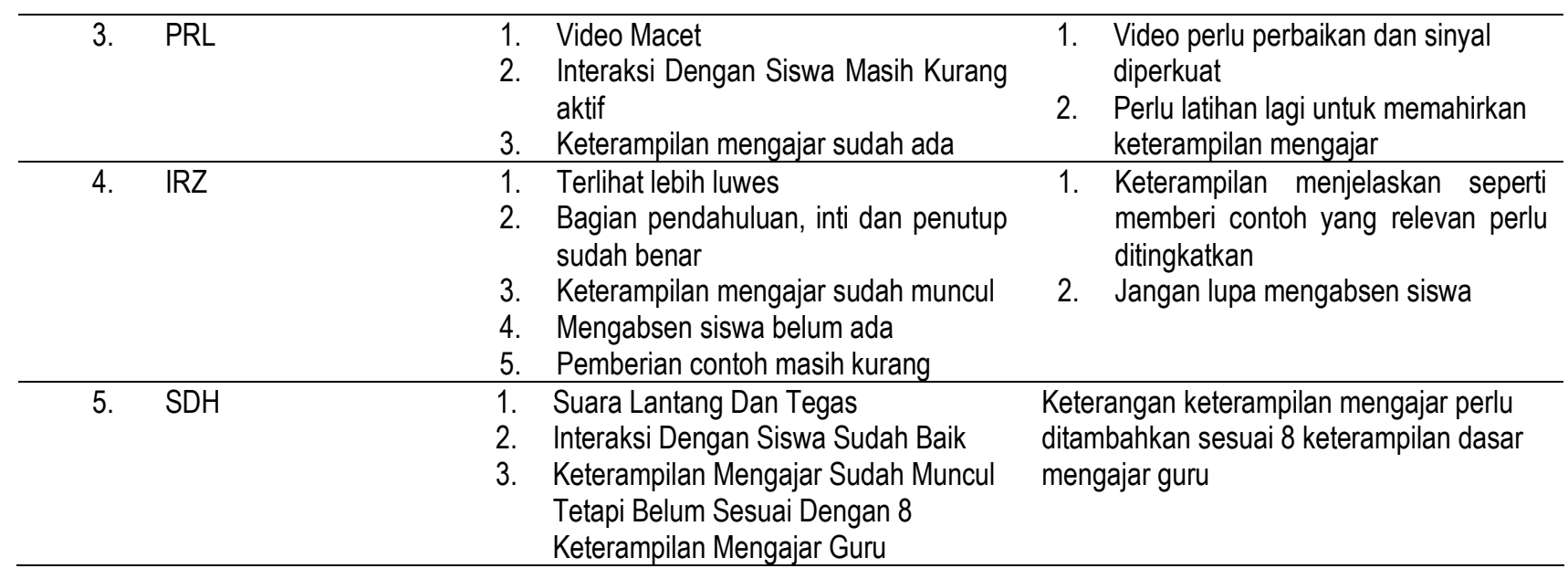

Rata-rata mahasiswa melakukan kesalahan dalam hal keterangan keterampilan mengajar yang belum ada, tahapan pembelajaran mulai dari pembukaan, inti dan penutup. Lebih lanjut, tujuan pembelajaran juga sering terlupa, keterampilan bertanya yang masih monoton dan penjelasan materi yang masih kurang dalam pemberian penjelasan.

\section{PENGAMATAN}

Dalam kegiatan pengamatan setiap pengamat melakukan observasi pada proyek yang dikerjakan oleh mahasiswa. Dalam pengamatan ini setiap observer melakukan pengamatan dengan mengisi lembar observasi yang telah disediakan. Dalam pengamatan itu yang menjadi komponen adalah keterampilan membuka pelajaran, keterampilan bertanya, keterampilan menjelaskan dan keterampilan mengelola kelas.

Tabel 2. Observasi Kegiatan Belajar Mahasiswa

\begin{tabular}{llc} 
No & Komponen yang Diamati & Skor \\
& & \\
\hline 1 & Mahasiswa mengembangan proyek & 2 \\
2 & Mahasiswa mengkomunikasikan ide-ide baru secara efektif & 2 \\
3 & Mahasiswa responsive terhadap perspetif baru dan beragam & 3 \\
4 & Mahasiswa menggabungkan masukan dan umpan balik & 2 \\
5 & Mahasiswa mengadopsi ide-ide baru & 3 \\
\hline Total & 11 \\
\hline Persentase & $55 \%$ \\
\hline Kategori & Cukup baik \\
\hline
\end{tabular}

\section{REFLEKSI}

Hasil refleksi menunjukkan bahwa setiap mahasiswa bersemangat dalam mengerjakan proyek yang telah ditugaskan. Namun belum maksimal dalam mengerjakannya. Maka perlu diadakan perbaikan dan monitoring serta dorongan untuk mengerjakan proyek dengan sungguh-sungguh. Dari pengamatan terdapat peningkatan kreativitas mahasiswa dalam mengerjakan proyek yang ditugaskan. 


\section{SIKLUS II}

\section{A. PERENCANAAN}

Dari hasil refleksi pada siklus I maka diadakan perbaikan dalam perencanaan pembelajaran selanjutnya yaitu dengan mengingatkan Kembali garis besar proyek yang dikerjakan oleh mahasiswa. Terutama dalam memunculkan keterampilan dasar mengajar guru dan urutan pembukaan, kegiatan inti, dan penutup. Tidak mesti semua keterampilan mengajar muncul akan tetapi apa yang semestinya muncul adalah ketrampilan menjelaskan, keterampilan membuka dan menutup pelajaran dan keterampilan bertanya. Jadi disetiap pertemuan minimal tiga keterampilan yang dilatih secara berulang.

\section{B. PELAKSANAAN}

Sesuai dengan rencana yang telah disusun setiap mahasiswa mempresentasikan proyeknya setelah mendapatkan masukan dari dosen dan teman sejawat. Masing-masing mahasiswa diberikan kesempatan 15 sampai 20 menit. Mahasiswa diingatkan untuk melakukan simulasi terlebih dahulu sebelum ditampilkan atau dipresentasikan tujuannya adalah untuk memastikan proyek yang dibuat berjalan dengan baik. Setelah presentasi mahasiswa lain memberikan masukan berupa umpan balik. Dosen selaku dosen pengampu mata kuliah juga memberikan masukkan.

Tabel 3. Hasil pelaksanaan proyek

\begin{tabular}{|c|c|c|c|}
\hline No & Mahasiswa & Kesalahan & Saran \\
\hline 1. & ADL & $\begin{array}{l}\text { 1. Gambar sudah baik dan lancar } \\
\text { 2. Keterangan keterampilan mengajar } \\
\text { sudah ada }\end{array}$ & $\begin{array}{l}\text { Sudah sesuai dengan masukan } \\
\text { sebelumnya }\end{array}$ \\
\hline 2. & NAS & $\begin{array}{l}\text { 1. Keterangan keterampilan mengajar } \\
\text { suda ada dan sesuai dengan } \\
\text { keterampilan dasar mengajar guru } \\
\text { 2. Tulisan sudah benar }\end{array}$ & $\begin{array}{l}\text { Sudah sesuai dengan masukkan } \\
\text { sebelumnya }\end{array}$ \\
\hline 3. & PRL & $\begin{array}{l}\text { 1. Video sudah lancer } \\
\text { 2. Interaksi Dengan Siswa sudah baik } \\
\text { 3. Keterampilan mengajar sudah ada }\end{array}$ & $\begin{array}{l}\text { Video sudah lancar dan inteaksi dengan } \\
\text { siswa sudah baik }\end{array}$ \\
\hline 4. & IRZ & $\begin{array}{l}\text { 1. Terlihat lebih luwes } \\
\text { 2. Bagian pendahuluan, inti dan penutup } \\
\text { sudah benar } \\
\text { 3. Keterampilan mengajar sudah muncul }\end{array}$ & $\begin{array}{l}\text { Sudah ada kegiatan mengabsen siswa dan } \\
\text { pemberian contoh-contoh }\end{array}$ \\
\hline 5. & SDH & $\begin{array}{l}\text { 1. Suara Lantang Dan Tegas } \\
\text { 2. Interaksi Dengan Siswa Sudah Baik } \\
\text { 3. Keterampilan Mengajar Sudah Muncul } \\
\text { dan Sesuai Dengan } 8 \text { Keterampilan } \\
\text { Mengajar Guru }\end{array}$ & $\begin{array}{l}\text { Keterangan keterampilan mengajar sudah } \\
\text { sesuai } 8 \text { keterampilan dasar mengajar guru }\end{array}$ \\
\hline
\end{tabular}

\section{PENGAMATAN}

Berdasarkan hasil pengamatan proyek yang telah dikerjakan mahasiswa sudah mengalami perubahan yang positif. Misalnya sudah ada keterangan keterampilan mengajar, mahasiswa sudah terampil mengajar, tidak grogi lagi dan sudah pandai dalam berinteraksi dengan siswa. 
BIODIK: Jurnal IImiah Pendidikan Biologi

Vol. 07, No. 03 (2021), Hal. 195 - 204

Tabel 4. Observasi Kegiatan Belajar Mahasiswa

\begin{tabular}{ccc} 
No & Komponen yang Diamati & Skor \\
& & 3 \\
\hline 1 & Mahasiswa mengembangan proyek & 3 \\
2 & Mahasiswa mengkomunikasikan ide-ide baru secara efektif & 4 \\
3 & Mahasiswa responsive terhadap perspetif baru dan beragam & 3 \\
4 & Mahasiswa menggabungkan masukan dan umpan balik & 3 \\
\hline 5 & Mahasiswa mengadopsi ide-ide baru & 11 \\
\hline & Total & $80 \%$ \\
\hline
\end{tabular}

\section{REFLEKSI}

Hasil refleksi menunjukkan bahwa setiap mahasiswa sudah mulai mengerti arahan dan focus proyek yang telah dilaksanakan. Mahasiswa sudah mempunyai pengalaman dari praktik sebelumnya. Kreativitas mahasiswa sudah tumbuh sesuai dengan tujuan penelitian.

\section{SIMPULAN}

Dengan model PjBL ini dikembangkan perangkat pembelajaran, bahan ajar, dan instrument evaluasi untuk meningkatkan kreativitas mahasiswa di Prodi Pendidikan Biologi FKIP Universitas Jambi. Metode penelitian mengunakan penelitian tindakan kelas (PTK) yang direncanakan 2 siklus. Adapun tahapnnya meliputi: perencanaan, pelaksanaan dan observasi, dan refleksi. Pada tahap perencanaan dilakukan diskusi kecil antar tim pengajar dan disepakati penerapan PJBL. Pada tahap pelaksanaan mahasiswa membuat proyek berupa video pembelajaran yang berisi keterampilan mengajar. Pada tahap pengamatan: mahasiswa diminta untuk mempresentasikan proyeknya tersebut didepan kelas secara virtual, kemudian dosen dan teman sejawat mengamati dan memberikan umpan balik. Terakhir tahap refleksi masukan dan komentar dari dosen dan teman sejawat dicatat dan dilakukan perbaikan proyek. Pada siklus 1 diperoleh hasil pengamatan $55 \%$ kategori cukup baik. Lalu diadakan perbaikan dari masukan dan komentar dari dosen dan teman sejawat maka pada siklus II mengalami kenaikan kreativitas mahasiswa pada skor $80 \%$ dalam kategori baik.

\section{RUJUKAN}

Allen, D. W. (1979). Microteaching: a personal review. 1-9.

Amobi, F. A. (2005). Preservice Teachers ' Reflectivity on the Sequence and Consequences of Teaching Actions in a Microteaching Experience. Teacher Education Quarterly, 32(1), 115-130. Anugraheni, I. (2018). Pengembangan Perangkat Pembelajaran Matematika Berbasis Pendidikan Karakter Kreatif Di Sekolah Dasar. Refleksi Edukatika: Jurnal IImiah Kependidikan, 8(2).

Asril, Z. (2017). Micro Teaching disertai dengan Pedoman Pengalaman Lapangan. In Raja Grafindo Persada.

Barbara, Nye, Spyros, Konstantopoulos, Larry, \& Hedges, V. (2004). How Large Are Teacher Effects? Educational Evaluation and Policy Analysis, 26(3), 237-257.

Benedetti, T. A., \& Reed, M. K. (1998). Supervising Student Teachers Using Peer Coaching. 1-19. Cochran-smith, M., \& Villegas, A. M. (2015). Framing Teacher Preparation Research : An Overview of the Field , Part 1. Journal of Teacher Education, 66(1), 7-20. https://doi.org/10.1177/0022487114549072 
Daryanto dan Rahardjo, M. (2012). Model Pembelajaran Inovatif. Yogyakarta: Gava Media.

Fathurrohman, M. (2016). Model Pembelajaran Inovatif: Alternatif desain Pembelajaran yang

Menyenangkan. Yogyakarta: Ar-Ruzz Media Group.

Isriani \& Puspitasari, D. (2015). Strategi Pembelajaran Terpadu: Teori, Konsep \& Implementasi.

Yogyakarta: Relasi Inti Media Group.

Fakhruddin. (2013). Micro Teaching (S. Syarnubi (ed.); 1st ed.). LP2 STAIN Curup-Bengkulu-Indonesia.

Fidalgo-blanco, Á., Sein-echaluce, M. L., García-peñalvo, F. J., \& Ángel, M. (2015). Computers in Human Behavior Using Learning Analytics to improve teamwork assessment. Computers in Human Behavior, 47, 149-156. https://doi.org/10.1016/j.chb.2014.11.050

Fitrisia, R., \& Jalinus, N. (2019). Komparasi Penggunaan Modul Cetak dengan Multimedia Interaktif Terhadap Hasil Belajar Ditinjau dari Kreativitas Siswa. INVOTEK: Jurnal Inovasi Vokasional Dan Teknologi, 19(2), 67-74.

Ivey, A. E., \& Authier, J. (1978). Microcounseling: Innovations in interviewing, counseling, psychotherapy, and psychoeducation. Charles C Thomas.

Jouwe, A. A., Situmorang, R. P., \& Sastrodihardjo, S. (2018). HUBUNGAN ANTARA KREATIVITAS GURU BIOLOGI DENGAN HASIL BELAJAR KOGNITIF SISWASMA KOTA SALATIGA.

Edudikara: Jurnal Pendidikan Dan Pembelajaran, 3(2), 213-222.

Knight, S. L., Lloyd, G. M., Arbaugh, F., Gamson, D., Mcdonald, S. P., \& Jr, J. N. (2014). Professional Development and Practices of Teacher Educators. Journal of Teacher Education, 65(4), 268 -270. https://doi.org/10.1177/0022487114542220

LPPM. (2021). Panduan Penyusunan Proposal Hibah Penelitian Inovasi Pembelajaran ( Teaching Grant ) Berbasis Proyek ( Project Based Learning -PjBL ) Tahun 2021 Lembaga Penelitian dan Pengabdian Kepada Masyarakat Universitas Jambi.

Mulyasa, E. (2014). Implementasi Kurikulum 2013. Bandung: PT Remaja Rosdakarya.

Saefudin, A \& Berdiati, I. (2014). Pembelajaran Efektif. Bandung: PT Remaja Roskadarya.

Widiasworo, E. (2016). Strategi Dan Metode Mengajar Siswa Diluar Kelas (Outdoor Leaning) Secara

Aktif, Kreatif, Inspiratif, Dan Komunikatif. Yogyakarta: Ar-Ruzz Media Group.

Nurhayati, N., Azmi, S., \& Suryati, T. (2014). Biologi untuk SMA/MA Kelas XI (4th ed.). YR.

Nurhayati, N., \& Wijayanti, R. (2017). Biologi untuk Siswa SMA/MA Kelas X (6th ed.). YRAMA WIDYA.

Nurhayati, N., \& Wijayanti, R. (2018). Biologi untuk Siswa SMA/MA Kelas XII (Vol. 5). YRAMA WIDYA.

Padmadewi, N. N., Artini, L. P., \& Agustini, D. A. (2017). Pengantar Micro Teaching (1st ed.). Depok: Rajawali Press.

Penyusun, T. (2010). Pedoman Praktik Pembelajaran Microteaching. Surakarta: FKIP UMS.

Royea, D. A., \& Nicol, C. (2018). Pre-service teachers' experiences of learning study: learning with and using variation theory. Educational Action Research, 00(00), 1-17. https://doi.org/10.1080/09650792.2018.1515094

Sadikin, A., \& Hakim, N. (2017). Dasar Dasar dan Proses Pembelajaran Biologi (1st ed.). Universitas Jambi.

Sari, R. T., \& Angreni, S. (2018). Penerapan model pembelajaran project based learning (PjBL) upaya peningkatan kreativitas mahasiswa. Jurnal Varidika, 30(1), 79-83.

Stahl, G., Sharplin, E., \& Kehrwald, B. (2018). Real-Time Coaching and Pre-Service Teacher Education. Springer. https://doi.org/10.1007/978-981-10-6397-8

Sudarisman, S. (2015). Memahami Hakikat Dan Karakteristik Pembelajaran Biologi Dalam Upaya 
Menjawab Tantangan Abad 21 Serta Optimalisasi Implementasi Kurikulum 2013. Florea : Jurnal Biologi Dan Pembelajarannya, 2(1), 29-35. https://doi.org/10.25273/florea.v2i1.403

Surya, A. P., Relmasira, S. C., \& Hardini, A. T. A. (2018). Penerapan model pembelajaran project based learning (PjBL) untuk meningkatkan hasil belajar dan kreatifitas siswa kelas III SD Negeri Sidorejo Lor 01 Salatiga. Jurnal Pesona Dasar, 6(1).

Wakimoto, T., Sasaki, H., Hirayama, R., Funaoi, H., Kubota, Y., Suzuki, H., \& Kato, H. (2019). Student Teachers ' Discourse During Puppertry-Based Microteaching. B. Eagan et.Al. (Eds): ICQE 2019, 234-244. https://doi.org/https://doi.org/10.1007/978-3-030-33232-7 